\title{
Target-Dependent Regulation of Retinal Nicotinic Acetylcholine Receptor and Tubulin RNAs During Optic Nerve Regeneration in Goldfish
}

\author{
*Virginia Hieber, *Bernard W. Agranoff, and *†Daniel Goldman \\ *Mental Health Research Institute and $\uparrow$ Department of Biological Chemistry, \\ University of Michigan, Ann Arbor, Michigan, U.S.A.
}

\begin{abstract}
A fundamental issue in central nervous system development regards the effect of target tissue on the differentiation of innervating neurons. We address this issue by characterizing the role the retinal ganglion cell target, i.e., the optic tectum, plays in regulating expression of tubulin and nicotinic acetylcholine receptor genes in regenerating retinal ganglion cells. Tubulins are involved in axonal growth, whereas nicotinic acetylcholine receptors mediate communication across synapses. Retinal ganglion cell axons were induced to regenerate by crushing the optic nerve. Following crush, there was a rapid increase in $\alpha$-tubulin RNAs ( 3 days), which preceded the increase in nicotinic acetylcholine receptor RNAs (10-15 days). Both classes of RNAs approached control levels by the time retinotectal synapses and functional recovery were restored (4-6 weeks). If the optic nerve was
\end{abstract}

repeatedly crushed or its target ablated, tubulin RNAs remained elevated, and the increase in receptor RNAs that would otherwise be seen 2 weeks after a single nerve crush did not occur. The interaction of retinal ganglion cell axons with their targets in the optic tectum appears, then, to exert a suppressive effect on the RNA encoding a cytoskeletal protein, tubulin, and an inductive effect on RNAs encoding nicotinic acetylcholine receptors involved in synaptic communication. Key Words: Nicotinic acetylcholine receptorsGoldfish-Optic nerve-Regeneration-SynaptogenesisTubulin. Hieber $\mathbf{V}$. et al. Target-dependent regulation of retinal nicotinic acetylcholine receptor and tubulin RNAs during optic nerve regeneration in goldfish. $J$. Neurochem. 58, 10091015 (1992).
Interactions between neuronal cells are crucial for transducing information throughout the nervous system. Regions of neuronal cells that are specialized for intercellular communication are known as synapses. At chemical synapses a neurotransmitter is released by the presynaptic cell and bound by receptors on the postsynaptic cell. The molecular mechanisms by which synapses form during development or are modified in the adult are not well understood. The best-studied synapse is the neuromuscular junction, where it appears that muscle innervation plays a critical role in regulating the expression of nicotinic receptors in the postsynaptic cell (Schuetze and Role, 1987). Electrical activity induced in the muscle by the presynaptic cell suppresses expression of embryonic-type receptors, whereas local nerve-muscle interactions induce adult- type receptors at the end plate. Therefore, in this case it is the presynaptic neuron that controls the level and distribution of nicotinic acetylcholine receptors (nAChRs) in the postsynaptic muscle cell.

Much less is known concerning the regulation of expression of synaptic proteins in the central nervous system. However, there is evidence that the innervating neuron can influence the expression of these molecules in their targets. In the case of neuronal $\mathrm{nAChRs}$ there is a correlation between innervation and $n A C h R ~ n \alpha$ and $\alpha 3$ gene expression in the chick optic tectum (Matter et al., 1990) and lateral spiriform nucleus (Daubas et al., 1990), respectively. Studies of nAChR gene expression in denervated or axotomized chick ciliary ganglia indicate that the $\alpha 3$ gene is induced by both pre- and postsynaptic factors (Boyd et al., 1988).
Received April 25, 1991; revised manuscript received July 26, 1991; accepted August 6, 1991.

Address correspondence and reprint requests to Dr. D. Goldman at Mental Health Research Institute, University of Michigan, Ann Arbor, MI 48109, U.S.A.
Abbreviations used: ACh, acetylcholine; BDNF, brain-derived neurotrophic factor; CNTF, ciliary neuronotrophic factor; GF, goldfish; nAChR, nicotinic acetylcholine receptor; NGF, nerve growth factor; TTX, tetrodotoxin. 
However, target removal, during ciliary ganglion development, did not prevent induction of acetylcholine (ACh)-activated currents in these cells (Engisch and Fischbach, 1990). The latter result indicates that the expression of functional nAChRs on these cells is not regulated by target innervation during development. Thus, there appears to be good evidence for a role of innervation in regulating expression of $\mathrm{nAChR}$ genes in the peripheral and central nervous systems. However, there is relatively little evidence for a role of the target in regulating this expression.

We have been using the goldfish (GF) retinotectal system to study the mechanisms by which nAChR genes, expressed in retinal ganglion cells, are regulated during synaptogenesis. The advantages of this system are its accessibility, the presence of relatively few cell types with a laminar distribution, and its ability to regenerate its optic nerve following injury (Grafstein, 1986). This regenerative capability is especially useful since it allows one to study the role target tissue plays in regulating expression of $\mathrm{nAChR}$ genes in retinal ganglion cells.

To determine whether the effects of the target on ganglion cell $n A C h R$ RNA expression are specific, we compared this expression to those encoding $\alpha$-tubulins. Tubulin is involved in axonal outgrowth, whereas nAChRs mediate communication across synapses. Thus we anticipated that these two classes of RNAs would be differentially regulated by target tissue. The results reported here substantiate this prediction and indicate the potential of target tissue to influence differentiation of innervating neurons.

\section{MATERIALS AND METHODS}

\section{Optic nerve crush and tectal ablation}

Common GF (Carassius auratus) were used in these studies. Fish $5-7 \mathrm{~cm}$ in length were maintained at $25^{\circ} \mathrm{C}$ in aerated tanks. Ganglion cell axons were induced to regenerate by crushing the right optic nerve just behind the orbit in tricaine methane sulfonate $(0.1 \%)$-anesthetized fish. Under similar conditions regenerating axons cross the site of crush after a 2- to 4-day delay (Bernhardt, 1989) and begin to innervate the contralateral tectum about 8-10 days later (Springer and Agranoff, 1977; Heacock and Agranoff, 1982). The left optic nerve of each fish was left intact, and the left retina served as an unoperated control. Tectal ablations were carried out on anesthetized GF after cutting into the skull with a small pair of scissors and lifting the flap over the right optic tectum. The tectum was removed by aspiration and the skull flap gently pressed back into position. Sham-operated fish underwent identical procedures but without optic nerve crush or tectal ablation, and retinas from these fish were used as additional controls. After surgery fish were returned to their tanks until they were killed.

\section{Isolation and characterization of cDNA clones}

The preparation of a GF retinal cDNA library and the cloning of $\mathrm{nAChR}$ cDNAs have been described (Cauley et al., 1989, 1990; Hieber et al., 1990a,b). These include the GF $\alpha-3$ and $\beta-2$ cDNAs (GF $\alpha-3$, GF $\beta-2)$, which are the GF homologues of the rat $\alpha-3$ and $\beta-2$ clones, and two novel
nAChR clones, GFn $\alpha-2$ and GFn $\alpha-3$, which are most similar to the rat $\beta-3$ clone. A radiolabeled chick $\alpha$-tubulin cDNA (Valenzuela et al., 1981) was used to isolate GF tubulin cDNA clones from the retinal library. One of these clones was subcloned into the M13mp19 bacteriophage vector for DNA sequence determination. The $5^{\prime}$ and $3^{\prime}$ ends were sequenced using the dideoxynucleotide chain termination method (Sanger et al., 1977). Sequence comparisons were made with the University of Wisconsin Genetics Computer Group sequence analysis software package.

\section{In situ hybridization}

Fish were dark-adapted and retinas were removed and processed for in situ hybridizations as previously described (Cauley et al., 1989, 1990). ${ }^{35} \mathrm{~S}$-Labeled sense and antisense RNA probes were prepared by runoff transcription of linearized pSP73 or pGEM4 vectors containing GF nAChR or tubulin cDNA inserts. RNA probes were alkaline-hydrolyzed to an average length of 100-200 nucleotides. Tissue preparation, hybridization, and posthybridization conditions were similar to those described previously (Cauley et al., 1989, 1990). Briefly, retinas were fixed in ice-cold $4 \%$ paraformaldehyde-phosphate-buffered saline ( $\mathrm{pH} \mathrm{7.4)} \mathrm{for} 2 \mathrm{~h}$ and then cryoprotected by immersion overnight in ice-cold $30 \%$ su-

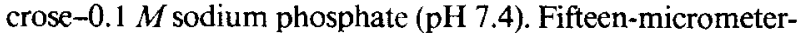
thick sections were cut on a cryostat and mounted on polylysine-coated slides. Prior to in situ hybridization, sections were digested with proteinase $\mathrm{K}(10 \mu \mathrm{g} / \mathrm{ml})$ for $5 \mathrm{~min}$ at $37^{\circ} \mathrm{C}$. Sections were covered with hybridization buffer containing $5 \times 10^{4} \mathrm{cpm} / \mu \mathrm{l}$ of radiolabeled-RNA probe and incubated at $55^{\circ} \mathrm{C}$ for approximately $21 \mathrm{~h}$. Posthybridization treatments included digestion with RNase $\mathrm{A}(50 \mu \mathrm{g} / \mathrm{ml})$ for $30 \mathrm{~min}$ at $37^{\circ} \mathrm{C}$ and a wash in $0.5 \times$ saline-sodium citrate at $55^{\circ} \mathrm{C}$ for $60 \mathrm{~min}$. Following dehydration slides were dipped in Kodak NTB-2 emulsion and exposed at $4^{\circ} \mathrm{C}$ for 4-5 days. Exposure times were such that the developed grains fell within the linear range of the emulsion. This linear range was determined by exposing slides with a constant amount of radiation for various lengths of time and counting grains. After development, sections were examined and photographed with dark-field optics using a Zeiss Axiophot microscope. Quantitation of RNA levels in these sections was performed by counting silver grains over 25-50 ganglion cells per retina. Cells were randomly chosen for this analysis and included cells that contained background grain levels (the number of cells containing background grain levels was about $20 \%$ in control retinas and approximately $10 \%$ in the 15-day-postcrush retina, independent of the probe used). The ratio of the total grains in ganglion cells of experimental retina to those in ganglion cells of control retina was calculated for each fish. These values were averaged for each time point (three fish) and reported as relative RNA level. Error bars are the standard error of the mean. Levels of significance $(p)$ were calculated using the two-tailed $t$ test.

\section{Tetrodotoxin (TTX) injections}

Five microliters of a $10^{-5} M$ TTX solution was pressureinjected into the vitreous humor of the right eye of fish. Injections were repeated every other day for up to 3 weeks. Control eyes received saline injections. The effectiveness of TTX blockade was measured using a behavioral assay (Davis and Schlumpf, 1984). Briefly, vision was monitored by a branchial suppression response evoked by a moving spot of light (conditioned response) that was classically conditioned to an electric shock unconditioned stimulus. 


\section{RESULTS}

To obtain cDNA probes for studying tubulin and $n A C h R$ gene expression in GF retina, retinal cDNA libraries were prepared and screened with either a chicken $\alpha$-tubulin (Valenzuela et al., 1981) or a mixed rat nAChR probe (Cauley et al., 1989). We have previously described the cloning and expression of the four GF nAChR subunit encoding genes GF $\alpha-3, \mathrm{GF} \beta-2$, GFn $\alpha$-2, and GFn $\alpha$-3 (Cauley et al., 1989, 1990; Hieber et al., $1990 a, b)$. Screening the cDNA library with the tubulin probe resulted in the purification and characterization of two $\alpha$-tubulin cDNAs. GF tubulin clone 6 was used to study $\alpha$-tubulin gene expression in the retina. Clone 6 is about $1.5 \mathrm{~kb}$ long. Approximately 400 bases at the $5^{\prime}$ and $3^{\prime}$ ends were sequenced and the deduced amino acid sequence was compared to the published chicken tubulin sequences (Monteiro and Cleveland, 1988; Pratt and Cleveland, 1988). This analysis showed clone 6 to encode an $\alpha$-tubulin (greater than $93 \%$ similarity to all $\alpha$-isoforms) with a terminal tyrosine residue found only in the $c \alpha 1$ and $c \alpha 8$ isoforms. The DNA sequence indicates that clone 6 encodes the complete $\alpha$-tubulin protein, as the $5^{\prime}$ end contains 60 nucleotides prior to the open reading frame that begins with an initiator methionine and the $3^{\prime}$ end contains an open reading frame that ends with a termination triplet followed by 70 nucleotides of $3^{\prime}$ untranslated sequence. The translated sequence is shown in Fig. 1.

Tubulin and nAChR RNAs were assayed in normal and regenerating retinal ganglion cells. The expression of tubulin in the regenerating GF optic nerve has been well documented at the protein level (Heacock and Agranoff, 1976, 1982). Axonal $\alpha$-tubulin labeling can increase over 40 -fold by about 3 weeks following optic nerve crush. Northern blot analysis indicates that this induction of tubulin protein synthesis is paralleled by an increase in retinal tubulin RNA (Neumann et al., 1983; Mizobuchi et al., 1990). We find by in situ hy-

\footnotetext{
MetArgGluCys I leSerValHisIleGlyGlnAlaGlyValGlnMetG lyAsnThrCys TrpGluLeuTy CCysLeuGluHisGly I leGInProAspGlyGl nMetP roSerAsnLYs ProValGlyGlyHisAspAspSerPheThrThrPhePheSerAspThrGlySerGlylys TyrValProArgAlaI lePheValAspLeuGluProThrVali leAspGluValArgThr GlyThrTyrArgGlnLeuPheHisProGluglnMet I leSerGlyLysGluAspAlaAla AsnAsnTyrAlaArgGiyHisTyrThrI leGly . . ( . . n . . . PheValAsp'TrpCys ProThrGlyPheLysValGly I leAsnTyrGInProProThrValValP roGlyGlyAsp LevAlaLysvalGinArgAlavalCysMet LeuSerAsnThrThrAla I leAlaGluAla TrpalaArgLeuAspHisLysPheAspleuMetTyrAlaLysArgAlaPheValHistrp TYIValGlyGluGlyMetGluGluGlyGluPheSerGluAlaArgGluAspMetAlaAla LeuGluLysAspTyrGluGluValGlyLeuAspSerGInGluAspGluGIuGluGlyGlu GluTyrEnd
}

FIG. 1. Deduced amino- and carboxy-terminal amino acid sequence of GF $\alpha$-tubulin clone 6 . Approximately 400 nucleotides of the 5 ' and $3^{\prime}$ ends of clone 6 were sequenced using the dideoxy chain termination method of Sanger (1977). Only one strand of the cDNA was sequenced. The annotation . . .). . . $)_{n}$. . . . in the middle of the sequence indicates a region of the clone that was not sequenced and, thus, encodes an undetermined number of amino acids. bridization that this previously observed increase in retinal $\alpha$-tubulin RNA occurs selectively in ganglion cells (Fig. 2A), $\alpha$-Tubulin RNA levels begin to rise about 3 days postcrush [2.2-fold increase, $p<0.05$ (two-tailed $t$ test)], peak about 15 days postcrush (4.5fold increase, $p<0.01$ ), and gradually decline to precrush levels over the following 2 to 3 months (Fig. 2B). The elevation of $\alpha$-tubulin RNA levels on about day 3 corresponds to the time at which crushed axons begin to regenerate (Springer and Agranoff, 1977; Heacock and Agranoff, 1982; Bernhardt, 1989). Because the probe used in these studies contained the complete $\alpha$ tubulin coding sequence, it is likely that it hybridizes to all $\alpha$-tubulin isoforms due to the high degree of nucleic acid similarity among these molecules.

In contrast to the information available on tubulin expression following nerve crush, very little is known about the regulation of synaptic proteins during regeneration. We have examined the expression of nAChRs in the rat $(F$. Hoover and D. Goldman, unpublished observations) and GF retina (Cauley et al., 1989, 1990). These proteins are expressed by retinal ganglion cells and their genes are coordinately induced during rat development. However, CNS neurons do not regenerate in the rat, and we have found that optic nerve crush caused a decline in ganglion cell nAChR RNAs (F. Hoover and D. Goldman, unpublished observations). In contrast, nAChR RNAs increase in abundance during GF optic nerve regeneration (Fig. 2). However, unlike tubulin RNA levels, which begin to increase by day 3 postcrush, nAChR RNAs appear to be either unaffected (GF $\alpha-3, \mathrm{GFn} \alpha-3)$ or declining (GF $\beta-2, \mathrm{GFn} \alpha-2)$ in abundance by days 3-6 (GF $\beta-2$ and GFn $\alpha-2$ are about $40 \%$ of control on day 3; $p$ $<0.01$ and $p<0.05$, respectively) and are then elevated by days $10-15$ postcrush (Fig. 2). By day 15 the increase above control was 3.5-fold for GF $\alpha-3(p<0.05)$, 1.9fold for GF $\beta-2(p<0.01) 2.5$-fold for GFn $\alpha-2(p$ $<0.01)$ and 2-fold for GFn $\alpha-3(p<0.01)$. This elevation coincides with a time at which regenerating axons have begun to contact their targets in the optic tectum (Springer and Agranoff, 1977; Heacock and Agranoff, 1982; Bernhardt, 1989). Over the next 2 to 3 months nAChR RNAs decline to normal ganglion cell levels.

The molecular mechanisms regulating expression of genes involved in neurite outgrowth and synaptogenesis are not well characterized. Optic nerve lesion results in a suppression of electrical activity in the optic nerve (Northmore, 1987). This decrease in impulse activity begins about 4 days postlesion, reaches a maximum level of depression about 10-14 days later, and is followed by recovery over the next few months (Northmore, 1987). Since muscle nAChR RNA levels are induced by suppression of muscle electrical activity (Goldman et al., 1988), we tested whether a similar mechanism regulated expression of neural $\mathrm{nAChR}$ genes in the regenerating ganglion cell. For this study, TTX $\left(5 \mu \mathrm{l}, 10^{-5} M\right)$ was injected into the vitreous hu- 
A

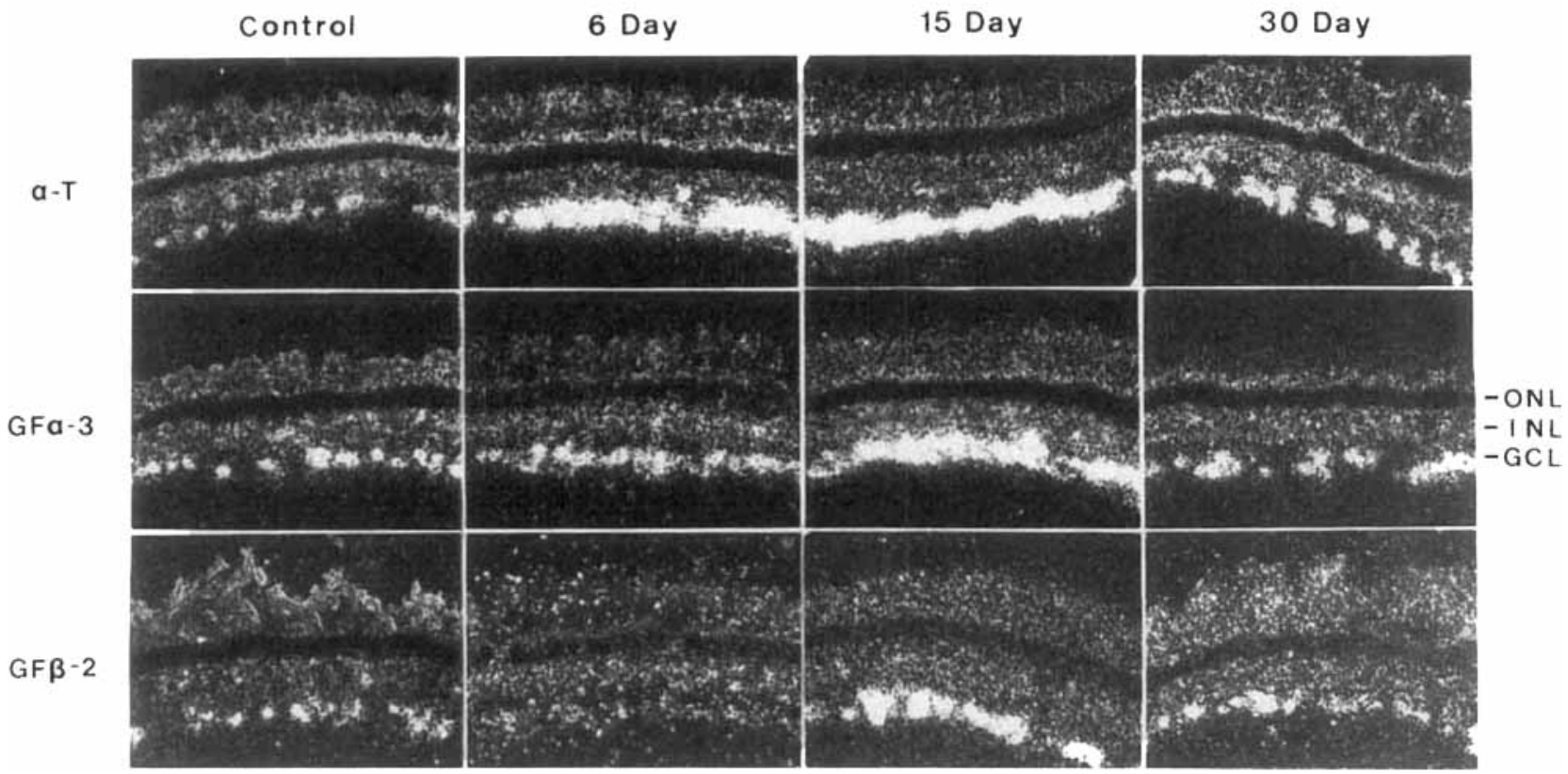

B

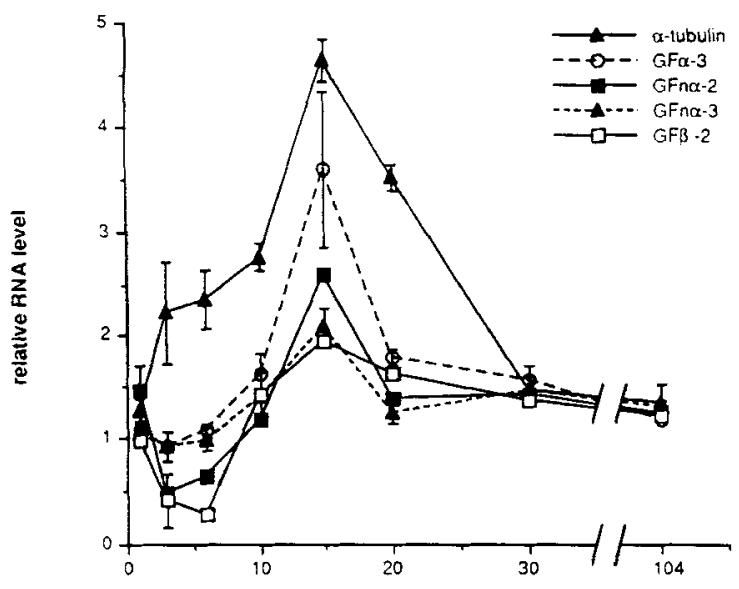

days post-crush
FIG. 2. Tirne course of expression of retinal $\alpha$-tubulin and nAChR RNAs during optic nerve regeneration. The right optic nerve was crushed on day 0 . Right and left retinas were removed at various times postcrush and processed for in situ hybridizations. A: In situ hybridization profiles of $\alpha$-tubulin and nAChR GF $\alpha-3$ and GF $\beta-2$ RNAs during optic nerve regeneration. Left retinas, which served as nonregenerating controls, showed no detectable changes in tubulin or nAChR RNA levels over the time course of the experiment. Although not shown, the GFn $\alpha-2$ and GFn $\alpha-3$ RNAs were regulated similarly to the GF $\beta-2$ and GF $\alpha-3$ RNAs, respectively (see quantitation in $B$ ). The column labeled "control" corresponds to the left retina of experimental fish. Photomicrographs were taken with a $20 \times$ objective using dark-field optics. $\alpha-\mathrm{T}, \alpha$-tubulin; ONL, outer nuclear layer; INL, inner nuclear layer; GCL, ganglion cell layer. B: Quantitation of $\alpha$-tubulin and nAChR GF $\alpha-3$, GF $\beta-2$, GFn $\alpha-2$, and GFn $\alpha-$ 3 RNA changes in retinal ganglion cells as a function of time after optic nerve crush. Left (control) and right (optic nerve-crushed) retinas were removed from fish at various times following optic nerve crush and processed for in situ hybridization. After the slides were developed, grains over ganglion cells were counted. Values (relative RNA level) are reported as the ratio of grains in regenerating ganglion cells to grains in control ganglion cells (see Materials and Methods). Each value represents the average from three individual fish. Error bars are the standard error of the mean. mor of the right eye of GF every other day for up to 3 weeks. Control eyes received saline injections. Effectiveness of TTX injections was monitored using a behavioral assay (Davis and Schlumpf, 1984). Three fish were killed at weekly intervals, and retinas processed for in situ hybridizations. No significant differences were found in the level of expression of any of the nAChR or $\alpha$-tubulin RNAs in control and TTX-treated retinas (data not shown). Therefore, we conclude that changes in electrical activity were not responsible for the changes in gene expression observed during regeneration.

Because nAChR RNA levels increased at a time when the regenerating axons were contacting the tec- tum (Springer and Agranoff, 1977; Heacock and Agranoff, 1982; Bernhardt, 1989), we tested whether this interaction was required for induction of $\mathrm{nAChR}$ gene expression. Retinal ganglion cell axons were prevented from contacting the tectum by repeated crushes over a 30-day period (Fig. 3). Under these conditions nAChR RNA levels remained fairly constant (GF $\alpha-3$, GFn $\alpha-3)$ or decreased [GF $\beta-2$ and GFn $\alpha-2 ; 11 \%(p$ $<0.01)$ and $74 \%(p<0.05)$ of control, respectively], at day 15 (Fig. 3B). That this effect on nAChR RNAs was selective is supported by the observation that the multiple nerve crushes had no effect on the elevation of $\alpha$-tubulin RNA that begins about 3 days postcrush (twofold increase, $p<0.01$ ) and continues to rise for 
A

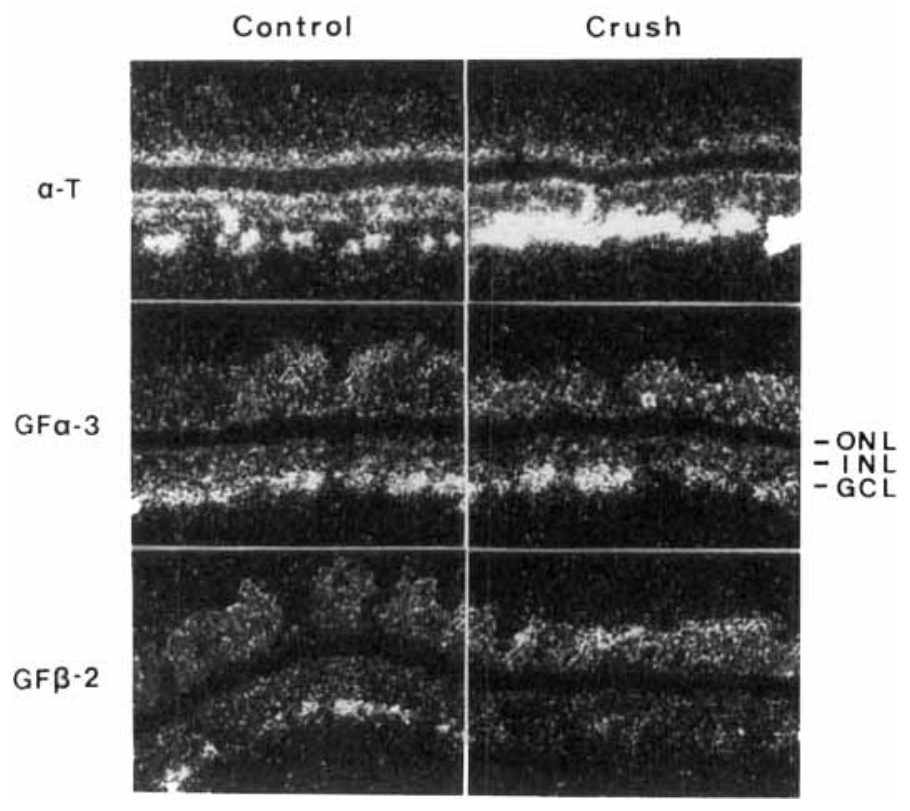

B

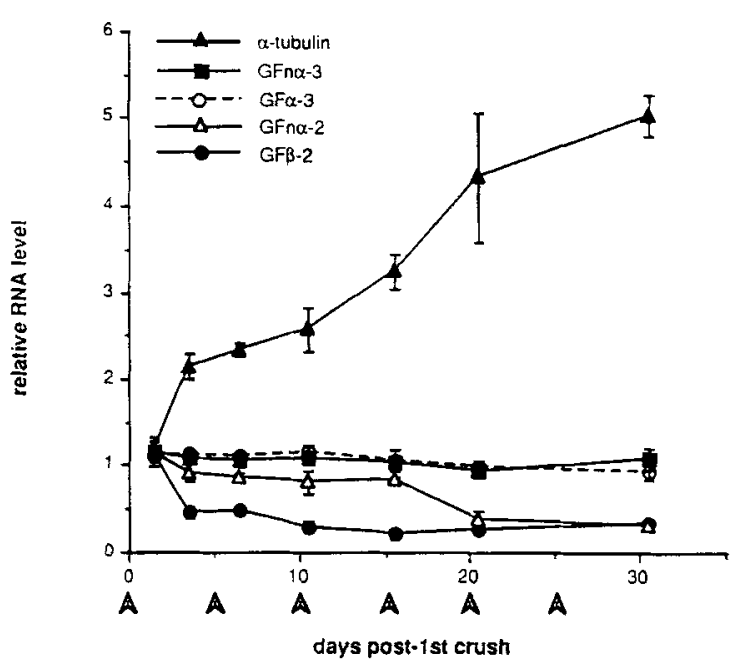

FIG. 3. Time course of expression of $\alpha$-tubulin and nAChR RNAs in retinas whose regenerating optic nerves were prevented from reaching the optic tectum. The right optic nerve was crushed repeatedly at 5-day intervals for up to 30 days. At various times right and left retinas were removed and processed for in situ hybridization. A: In situ hybridization profile of $\alpha$-tubulin and nAChR GF $\alpha-3$ and GF $\beta$-2 RNAs 15 days after the initial optic nerve crush. Control corresponds to the left retina. Abbreviations are as in the legend to Fig. 2. B: Quantitation of $\alpha$-tubulin and nAChR subunit RNA changes in retinal ganglion cells as a function of time after the initial optic nerve crush. Arrowheads indicate the days on which optic nerves were crushed. See the legend to Fig. 2 for details.

the duration of the experiment [fivefold increase by day 30, $p<0.01$ (Fig. 3)]. Consistent with this result we found that tectal ablation also prevented the increase in nAChR RNAs in the contralateral retina at day 15 (Table 1). Under these conditions nAChR RNA levels did not differ significantly from control levels at this time, whereas $\alpha$-tubulin RNA showed a sixfold increase $(p<0.01)$ (Table 1). This result is consistent with the observation that tectal ablation prevents axonal tubulin

TABLE 1. Effect of tectal ablation on relative $R N A$ levels in retinal ganglion cells

\begin{tabular}{lcc}
\hline \multicolumn{1}{c}{ RNA } & Ablated fish & \\
\hline$\alpha$-Tubulin & $6.01 \pm 0.54$ & Control fish $^{b}$ \\
GF $\alpha-3$ & $1.02 \pm 0.07$ & $0.95 \pm 0.11$ \\
GFn $\alpha-3$ & $0.99 \pm 0.12$ & $1.06 \pm 0.17$ \\
GFn $\alpha-2$ & $0.83 \pm 0.09$ & $0.98 \pm 0.06$ \\
GF $\beta-2$. & $0.80 \pm 0.11$ & $0.98 \pm 0.11$ \\
\hline
\end{tabular}

\footnotetext{
${ }^{a}$ Retinas were removed from fish 15 days after tectal ablation and processed for in situ hybridization as described in Materials and Methods. After developing the slides, grains over the ganglion cells were counted. Relative RNA levels are reported as the ratio of grains in ganglion cells contralateral to the ablated tectum to grains in ipsilateral ganglion cells (see Materials and Methods). Each value represents the average from three fish \pm SEM.

${ }^{b}$ Retinas were removed from sham-operated fish and relative RNA levels determined as indicated in footnote $a$.
}

labeling from returning to normal values during GF optic nerve regeneration (Grafstein et al., 1987).

\section{DISCUSSION}

The results presented here indicate differential regulation of tubulin and nAChR RNAs during optic nerve regeneration. They are temporally consistent with the roles these proteins play in axon outgrowth and synaptic communication. As tubulin contributes to the cytoskeleton, increased expression of its RNA will accommodate the requirements of the growing axon. The return of tubulin RNA to precrush levels in the regenerating ganglion cell is dependent upon its interaction with the optic tectum. These results are consistent with those characterizing tubulin RNA levels in developing and regenerating peripheral neurons (Miller et al., 1987, 1989). The mechanism by which these changes in tubulin RNA occur is not known but may involve autoregulation of tubulin RNA stability by changing intracellular tubulin monomer levels (Pachter et al., 1987). Decreasing intracellular concentrations of monomer result in increased levels of tubulin mRNA by increasing its stability (Pachter et al., 1987). Consistent with this idea is the observation that during regeneration axonal tubulin labeling increases over 40fold (Heacock and Agranoff, 1982), yet tubulin synthesis in the ganglion cell increases only about 4-fold 
(Giulian et al., 1980). These data imply that tubulin transport from the cell body into the axon increases about 10-fold during axon outgrowth. This would result in a net decrease in the concentration of monomer in the cell body, causing increased stability of its mRNA. Once the regenerating axons have reached their targets in the tectum, they stop growing and axonally transported tubulin slowly declines over the following 2 months. This would increase the monomer concentration in the ganglion cell, causing a decline in its mRNA due to decreased stability.

In contrast to tubulin RNA levels, nAChR RNAs increase at a time when the ganglion cell axons begin reinnervating the tectum. Although these receptors do not appear to mediate directly communication across retinotectal synapses, presynaptic nAChRs can modulate this communication (King, 1990). In addition, postsynaptic nAChRs likely mediate communication with cholinergic amacrine cells (Ariel and Daw, 1982). As these receptors are involved in the flow of visual information from retina to brain, one might predict that cell-cell interactions regulate their expression. Both the multiple crush and the tectal ablation experiments supported this prediction. These results suggest the existence of a trophic factor released from the tectum that directly or indirectly influences $\mathrm{nAChR}$ RNA levels in the ganglion cells.

A number of known target-derived trophic molecules influence neuronal phenotype. For example, nerve growth factor (NGF) induces both differentiation of PC12 cells and expression of functional nAChRs (Amy and Bennett, 1983). Ciliary neuronotrophic factor (CNTF), found in eye tissue, increases neuronal survival in culture and suppresses expression of the $\alpha$ bungarotoxin binding component found on chick autonomic neurons (Halvorsen and Berg, 1989). Brainderived neurotrophic factor (BDNF) is especially interesting, as it is synthesized in targets of retinal ganglion cell axons and supports survival of these neurons in culture (Leibrock et al., 1989). A possible alternative to the existence of a target-derived trophic substance is the presence of a regulatory molecule endogenous to the ganglion cell, the activity of which is influenced by ganglion cell axons interacting with the optic tectum. The mechanism by which nAChR RNAs would eventually return to precrush levels is not clear but may involve a change in the level/activity of this putative factor as stable synapses form.

The changes in RNA expression reported here, along with previous studies of axonally transported proteins (Benowitz et al., 1983; Grafstein et al., 1987), indicate that a number of regulatory mechanisms operate during optic nerve regeneration and synaptogenesis. As shown here some of these controls depend upon ganglion cell axon interactions with the optic tectum. In this case the optic tectum can exert either a positive or a negative effect on the expression of RNAs encoding nAChRs or $\alpha$-tubulins, respectively, in the presynaptic retinal ganglion cell.
Acknowledgment: We thank Keith Cauley and John Bouchey for isolating and sequencing the fish tubulin cDNA and Dr. Roger Davis for performing behavioral assays on TTX-treated fish. We also thank Dr. Anne Heacock, Hebe Guardiola-Diaz, Frank Hoover, Julie Staple, and John Bouchey for critically reading the manuscript. This work was supported by grants from the NIH and Lucille P. Markey Charitable trust awarded to B.W.A. and D.G.

\section{REFERENCES}

Amy C. M. and Bennett E. L. (1983) Increased sodium ion conductance through nicotinic acetylcholine receptor channels in PC12 cells exposed to nerve growth factors. J. Neurosci. 3, 1547-1553.

Ariel M. and Daw N. W. (1982) Pharmacological analysis of directionally sensitive rabbit retinal ganglion cells. J. Physiol. 324, $161-185$.

Benowitz L. I., Yoon M. G., and Lewis E. R. (1983) Transported proteins in the regenerating optic nerve: regulation by interactions with the optic tectum. Science 222, 185-188.

Bernhardt R. (1989) Axonal pathfinding during the regeneration of the goldfish optic pathway. J. Comp. Neurol. 284, 119-134.

Boyd R. T., Jacob M. H., Couturier S., Ballivet M., and Berg D. K. (1988) Expression and regulation of neuronal acetylcholine receptor mRNA in chick ciliary ganglia. Neuron 1, 495-502.

Cauley K. C., Agranoff B. W., and Goldman D. (1989) Identification of a novel nicotinic acetylcholine receptor structural subunit expressed in goldfish retina. $J$. Cell. Biol. 108, 637-645.

Cauley K. C., Agranoff B. W., and Goldman D. (1990) Multiple nicotinic acetylcholine receptor genes are expressed in goldfish retina and tectum. $J$. Neurosci. 10, 670-683.

Daubas P., Devillers-Thiery A., Geoffroy B., Martinez S., Bessis A., and Changeux J. P. (1990) Differential expression of the neuronal acetylcholine receptor $\alpha 2$ subunit gene during chick brain development. Neuron 5, 49-60.

Davis R. E. and Schlumpf B. E. (1984) Visual recovery in goldfish following unilateral optic tectum ablation: evidence of competition between optic axons for tectal targets. Behav. Brain Res. 13, 287-291.

Engisch K. L. and Fischbach G. D. (1990) The development of ACHand GABA-activated currents in normal and target-deprived embryonic chick ciliary ganglia. Dev. Biol. 139, 417-426.

Giulian D., Ruisseaux H. D., and Cowburn D. (1980) Biosynthesis and intraaxonal transport of proteins during neuronal regeneration. J. Biol. Chem. 255, 6494-6501.

Goldman D., Brenner H. R., and Heinemann S. (1988) Acetylcholine receptor $\alpha-, \beta-, \gamma-$, and $\delta$-subunit mRNA levels are regulated by muscle activity. Neuron 1, 329-333.

Grafstein B. (1986) The retina as a regenerating organ, in The Retina A Model for Cell Biology Studies, Part II (Adler R, and Farber D., eds), pp. 275-335. Academic Press, Orlando, Florida.

Grafstein B., Burmeister D. W., McGuinness C. M., Perry G. W., and Sparrow J. R. (1987) Role of fast axonal transport in regeneration of goldfish optic axons. Prog. Brain Res. 71, 113120.

Halvorsen S. W. and Berg D. K. (1989) Specific down-regulation of the $\alpha$-bungarotoxin binding component of chick autonomic neurons by ciliary neuronotropic factor. $J$. Neurosci. 9, 3673 3680

Heacock A. M. and Agranoff B. W. (1976) Enhanced labeling of retinal protein during regeneration of optic nerve in goldfish. Proc. Natl. Acad. Sci. USA 73, 828-832.

Heacock A. M. and Agranoff B. W. (1982) Protein synthesis and transport in the regenerating goldfish visual system. Neurochem. Res. 7, 771-788.

Hieber V., Bouchey J., Agranoff B. W., and Goldman D. (1990a) Nucleotide and deduced amino acid sequence of the goldfish neural nicotinic acetylcholine receptor $\alpha-3$ subunit. Nucleic Acids Res. 18, 5293.

Hieber V., Bouchey J., Agranoff B. W., and Goldman D. (1990b) 
Nucleotide and deduced amino acid sequence of the goldfish neural nicotinic acetylcholine receptor $\beta-2$ subunit. Nucleic Acids Res. 18, 5307.

King W. M. (1990) Nicotinic depolarization of optic nerve terminals augments synaptic transmission. Brain Res. 527, 150-154.

Leibrock J., Lottspeich F., Hohn A., Hofer M., Hengerer B., Masiakowski P., Thoenen H., and Barde Y.-A. (1989) Molecular cloning and expression of brain-derived neurotropic factor. $\mathrm{Na}$ ture 341, 149-152.

Matter J. M., Matter-Sadzinski L., and Ballivet M. (1990) Expression of neuronal nicotinic acetylcholine receptor genes in the developing chick visual system. EMBO J. 9, 1021-1026.

Miller F. D., Naus C. C. G., Durand M., Bloom F. E., and Milner R. J. (1987) Isotypes of $\alpha$-tubulin are differentially regulated during neuronal maturation. J. Cell Biol. 105, 3065-3073.

Miller F. D., Tetzlaff W., Bisby M. A., Fawcett J. W., and Milner R. J. (1989) Rapid induction of the major embryonic $\alpha$-tubulin mRNA, t $\alpha 1$, during nerve regeneration in adult rats. $J$. Neurosci. 9, 1452-1463.

Mizobuchi T., Yagi Y., and Mizuno A. (1990) Changes in $\alpha$-tubulin and actin gene expression during optic nerve regeneration in frog retina. $J$. Neurochem. 55, 54-59.

Monteiro M. J. and Cleveland D. W. (1988) Sequence of chicken $\mathrm{c} \beta 7$ tubulin. Analysis of a complete set of vertebrate $\beta$-tubulin isotypes. J. Mol. Biol. 199, 439-446.
Neumann D., Scherson T., Ginzburg I., Littauer U. Z., and Schwartz M. (1983) Regulation of mRNA levels for microtubule proteins during nerve regeneration. FEBS Lett. 162, 270-276.

Northmore D. P. M. (1987) Neural activity in the regenerating optic nerve of the goldfish. J. Physiol. 391, 299-312.

Pachter J. S., Yen T. J., and Cleveland D. W. (1987) Autoregulation of tubulin expression is achieved through specific degradation of polysomal tubulin mRNAs. Cell 51, 283-292.

Pratt L. F. and Cleveland D. W. (1988) A survey of the $\alpha$-tubulin gene family in chicken: unexpected sequence heterogeneity in the polypeptides encoded by five expressed genes. EMBO J.7, 931-940.

Sanger F., Nicklen S., and Coulson A. R. (1977) DNA sequencing with chain-terminating inhibitors. Proc. Natl. Acad. Sci. USA 74, 5463-5467.

Schuetze S. M. and Role L. W. (1987) Developmental regulation of nicotinic acetylcholine receptors. Annu. Rev. Neurosci. 10, 403457.

Springer A. and Agranoff B. W. (1977) The effect of temperature on rate of goldfish optic nerve regeneration: a radioautographic and behavioral study. Brain Res. 128, 405-415.

Valenzuela P., Quiroga M., Zaldivar J., Rutter W. J., Kirschner M. W., and Cleveland D. W. (1981) Nucleotide and corresponding amino acid sequences encoded by $\alpha$ and $\beta$ tubulin mRNAs. Nature 289, 650-655. 